\title{
TV corporativa no Brasil: caracterização, conceituação e produção de sentido
}

\author{
Autor: Rakelly Calliari Schacht \\ Orientador: Florentina das Neves Souza
}

\begin{abstract}
Resumo: Estuda a caracterização, conceituação e recuperação histórica recente da TV Corporativa no Brasil, com o objetivo de compreender o veículo enquanto produtor de sentidos e parte integrante da comunicação nas organizações, sob a perspectiva crítica do paradigma da sensação proposto pelo filósofo alemão Christoph Türcke. As reflexões resultantes do trabalho apontam para o desenvolvimento da TV Corporativa como fruto de uma escalada da demanda por sensações no contexto hipercapitalista. Neste estágio, cada organização se torna potencialmente uma emissora de choques audiovisuais a fim de capturar a atenção e mobilizar emocionalmente seu público, neste caso formado majoritariamente por funcionários de grandes empresas privadas. A pesquisa realizada tem caráter exploratório e serviuse de revisão bibliográfica, análise documental e entrevistas com grandes empresas e produtoras audiovisuais.
\end{abstract}

Palavras-chave: Televisão. Comunicação nas organizaçoes. Organizações. Meios de comunicação. Comunicação de massa. Sentidos e sensações. 


\title{
Business TV In Brazil: Characterization, conceptualization and production of meaning
}

\begin{abstract}
Studies the characterization, conceptualization and recent historical recovery of Business $T V$ in Brazil, aiming to understand this vehicle as a producer of meanings and an integral part of organizational communication, under the critical perspective of the paradigm of sensation proposed by the German philosopher Christoph Türcke. The reflections arising from the study point to the development of Business TV as result of an increasing demand for sensations in the context of hypercapitalism. At this stage, every organization turns into a potentially sender of audiovisual shocks, in order to capture the attention and emotionally mobilize its audience, that in the present case consists mainly by employees of large private companies. The research here carried out has an exploratory profile and was based on literature review, document analysis and interviews with major companies and audiovisual producers.
\end{abstract}

Keywords: Television, Communication in organizations, Media organizations, Mass communication, Senses and sensations

Dissertação completa disponível em: http://www.bibliotecadigital.uel.br/ document/?view $=$ vtls000190256 